\title{
Synthesis of a coumarin/phenanthridine-fused heterocycle as a lockable colorimetric fluorescence molecular switch
}

\author{
Shih-Hsun Su and Ding-Yah Yang* \\ Department of Chemistry, Tunghai University, No. 181, Section 3, Taichung Port Road, \\ Taichung City 40704, Taiwan \\ E-mail:yang@thu.edu.tw
}

\begin{abstract}
A coumarin/phenanthridine-fused heterocycle was synthesized via base-mediated annulation of $\mathrm{N}$-alkylquinolinium salt and coumarin. Its potential to function as a lockable molecular switch by use of $\mathrm{pH}$ and redox chemistry as external stimuli was evaluated. When treated with an acid, the light yellow, fluorescent ring-closed heterocycle is instantly switched to the red, non-fluorescent ring-opened iminium salt, and this process is reverted by adding a base. The acidichromism can be selectively "locked" by converting the ring-closed and -opened compounds to their "pH-inert" forms via NBS oxidation and $\mathrm{NaBH}_{4}$ reduction, respectively. A lockable colorimetric fluorescence molecular switch is introduced.
\end{abstract}

Keywords: Coumarin, phenanthridine, annulation, acidichromism, fluorescence molecular switch

\section{Introduction}

Molecules or ions which can be switched from one configuration to another by an external perturbation continue to receive considerable attention, partly due to their potential applications in molecular information processing and storage. ${ }^{1}$ Most examples of molecular switches typically consist of two stable states distinguishable by physical or chemical properties, which are interchangeable through the alteration of controllable parameters such as $\mathrm{pH}$, temperature, light, redox potential, and metal ions. ${ }^{2}$ Recently, Cronin and coworkers ${ }^{3}$ reported the use of a $\mathrm{pH}^{-}$ modulated cyclization of a phenanthridine derivative to switch between two states with complementary redox activities that can then be selectively "locked" by oxidation or reduction. In this system, the phenanthridine and its corresponding phenanthridinium derivative are interchangeable via $\mathrm{pH}$ control and can also be further converted to their " $\mathrm{pH}$-inert" forms by chemical oxidation and reduction, respectively. This combination of two separate control parameters creates a switchable system with a gated response where one parameter controls the 
other, thus allowing for read-write and read-only behavior. ${ }^{4}$ The four compounds were found to possess similar emission spectra, therefore the switching between the two states can only be monitored by use of UV-vis and proton NMR spectrometry. Since fluorescence emission is considered to be one of the most attractive signal outputs of switching materials owing to its high sensitivity, easy detection and low-cost procedure, ${ }^{5}$ we believe the fluorescence detection of the output properties of this switching system can be realized by incorporation of a fluorophore such as coumarin to the phenanthridine moiety. Here, we report the synthesis of a new fluorescent coumarin/phenanthridine-fused heterocycle and subsequent evaluation of its potential to function as a lockable molecular switch by use of $\mathrm{pH}$ and redox chemistry as external stimuli.

\section{Results and Discussion}

Scheme 1 shows the preparation of the coumarin and phenanthridine-fused heterocycle 1. It started with first converting 7-dimethylamino-4-hydroxycoumarin $(2)^{6}$ to 4-chloro-7dimethylamino-2-oxo- $2 H$-chromene-3-carbaldehyde (3) by treating it with phosphorus oxychloride in DMF. The subsequent condensation of $\mathbf{3}$ and $\mathrm{N}$-(2-bromoethyl)-4methylquinolinium bromide (5) in the presence of triethylamine as a base in ethanol under reflux conditions gave the intermediate iminium bromide $6,{ }^{7}$ which was further reacted with aniline in chloroform at room temperature to afford the target compound 1. Compound $\mathbf{5}$ was prepared by refluxing the commercially available 4-methylquinoline (4) with 1,2-dibromoethane as literature described. ${ }^{8}$ The molecular structure of 1 was confirmed by the observation of two characteristic singlet aromatic hydrogen absorption peaks at 8.24 and $8.05 \mathrm{ppm}$ as well as the singlet imidazolidinyl hydrogen absorption peak at $5.37 \mathrm{ppm}$ on the proton NMR spectra. Similar mechanisms for the formation of intermediate $\mathbf{6}^{7}$ and compound $\mathbf{1}^{3 \mathrm{~b}}$ have been previously investigated.

With the heterocycle $\mathbf{1}$ in hand, its acidichromic properties were then explored. When treated with an acid ( $\mathrm{HBr})$, the light yellow, fluorescent ring-closed $\mathbf{1}$ is converted to the corresponding red, non-emissive ring-opened iminium salt 7 (Scheme 2). This process can be reverted by adding a base $\left(\mathrm{Et}_{3} \mathrm{~N}\right)$. Figures 1 and 2 show the UV-vis and emission spectra of compounds 1, 7-9 in acetonitrile, respectively. Interestingly, the UV-vis spectra of $\mathbf{1}$ exhibit multiple absorption patterns. By comparison with the absorption spectra of the phenanthridine derivative reported by Cronin, ${ }^{3}$ the peaks at 250 and $340 \mathrm{~nm}$ were unambiguously identified to be the absorption of phenanthridine chromophore. The other absorption bands around 300 and $375 \mathrm{~nm}$ were attributed to the intrinsic benzene/coumarin-fused chromophore. Also, compound 1 is fluorescent due to the presence of the dimethylaminocoumarin fluorophore. Conversely, compound 7 is red $\left(\lambda_{\max }=494 \mathrm{~nm}\right.$ ) owing to the highly conjugated coumarin/phenanthridiniumfused chromophore, but is practically not fluorescent since the fluorescence is presumably quenched by the electron-deficient, positively charged phenanthridinium moiety. 

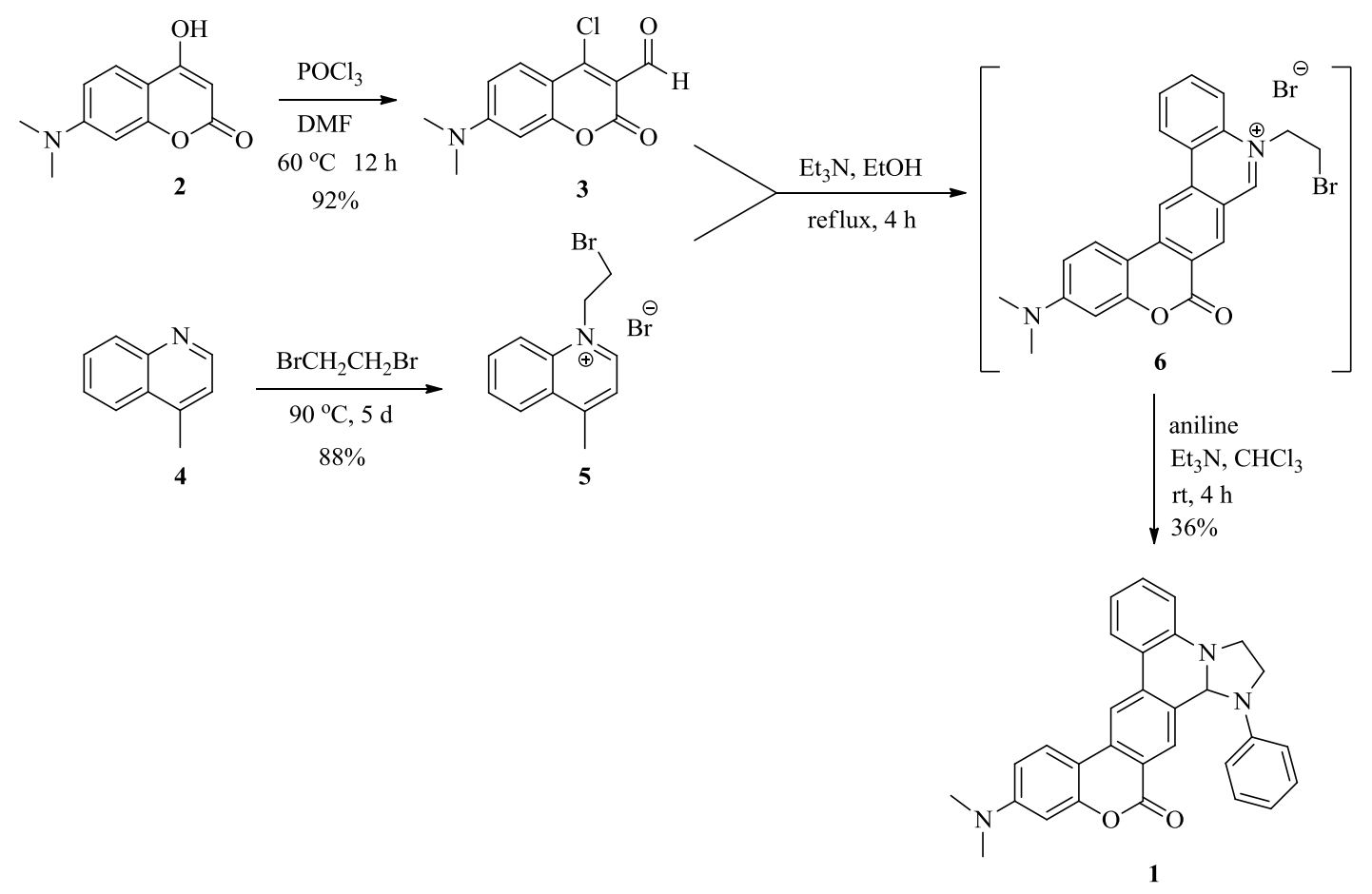

Scheme 1. Synthetic route for the title compound 1.<smiles>CN(C)c1ccc2c(c1)oc(=O)c1cc3c(cc12)-c1ccccc1N1CCN(c2ccccc2)C31</smiles>

light yellow and fluorescent<smiles>CN(C)c1ccc2c(c1)oc(=O)c1cc3c(cc12)c1ccccc1n3CC[Hg]</smiles><smiles></smiles>

red and non-fluorescent

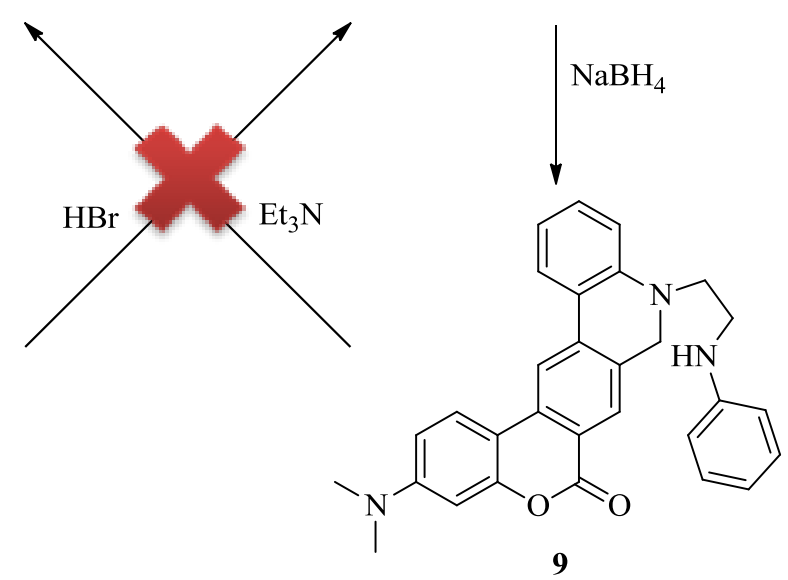

Scheme 2. A lockable colorimetric fluorescence molecular switch. 


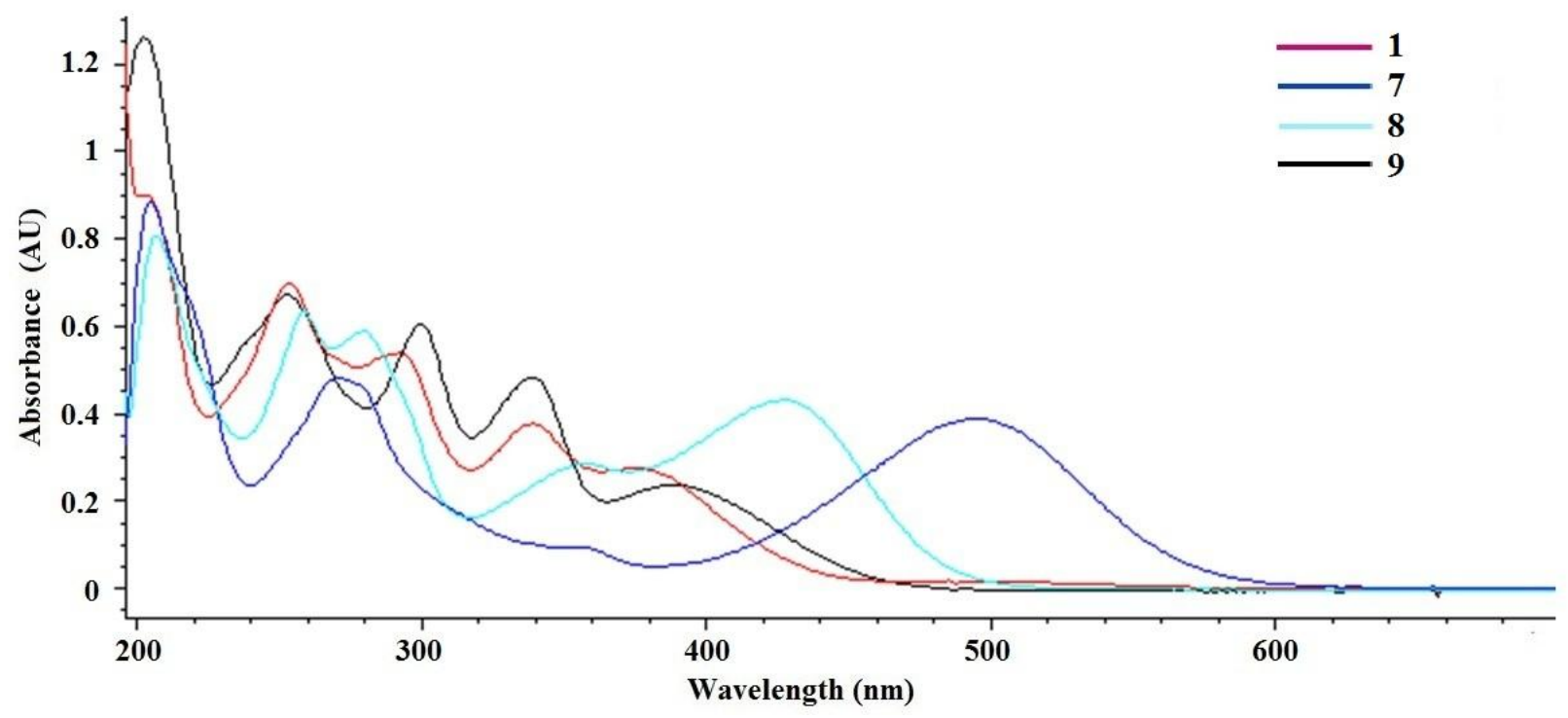

Figure 1. UV-vis spectra of $\mathbf{1}$ and 7-9 $\left(1.0 \times 10^{-5} \mathrm{M}\right.$ in $\left.\mathrm{CH}_{3} \mathrm{CN}\right)$ at room temperature.

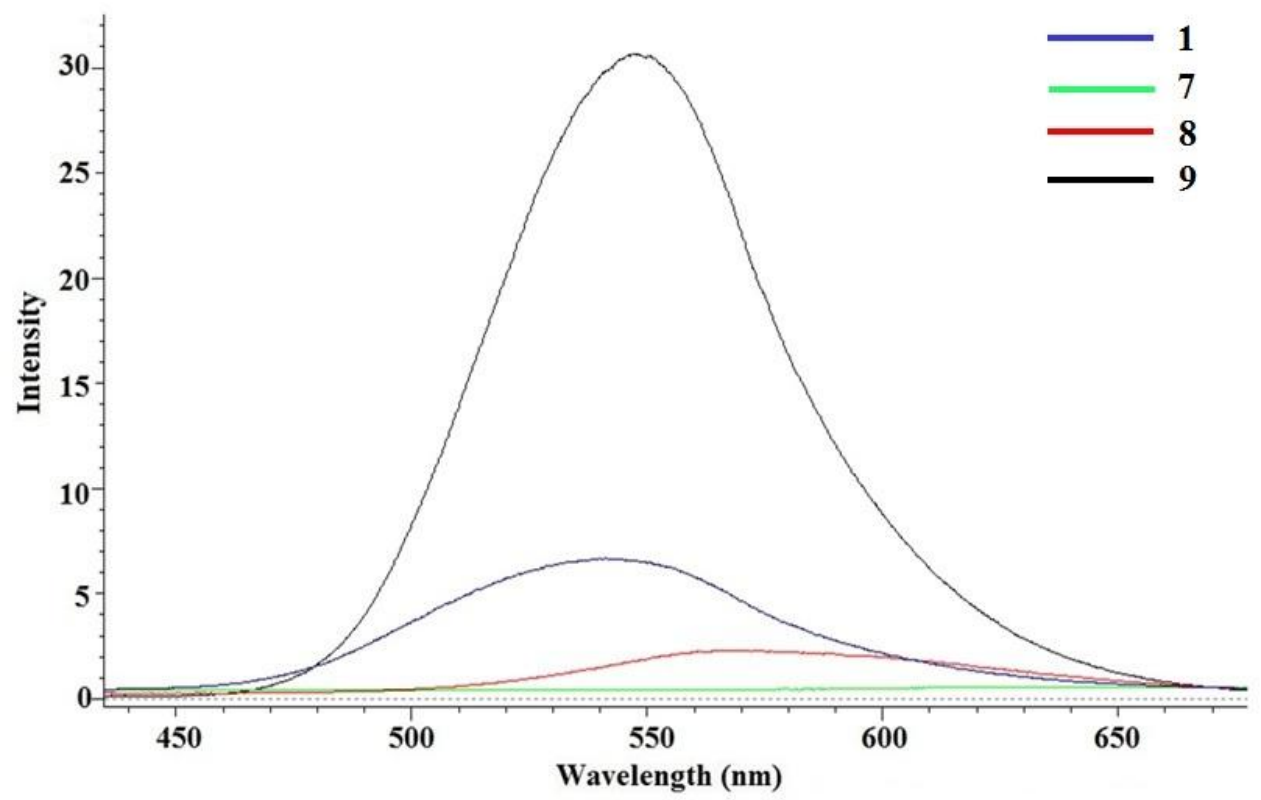

Figure 2. Emission spectra of $\mathbf{1}$ and 7-9 $\left(3.0 \times 10^{-6} \mathrm{M}\right.$ in $\left.\mathrm{CH}_{3} \mathrm{CN}\right)$ at room temperature.

Table 1 summarizes the fluorescence parameters of compounds 1, 7-9 in acetonitrile. Among them, compound 9 has the highest fluorescence quantum yield with the $\Phi_{f}$ value of 0.133 , follows by compound $1\left(\Phi_{f}=0.035\right)$. The $\Phi_{f}$ difference between $1\left(\lambda_{\mathrm{em}}=541 \mathrm{~nm}\right)$ and $7\left(\lambda_{\mathrm{em}}=\right.$ $646 \mathrm{~nm}$ ) is determined to be more than 35-fold. Figure 3 shows the fluorescence spectra of 1 in the absence and presence of excess triethylamine, indicating that the added base triethylamine does not cause any increase or decrease in fluorescence intensity of $\mathbf{1}$. 
Table 1. Fluorescence parameters for compounds 1, 7-9 in acetonitrile

\begin{tabular}{llll}
\hline Compound & $\lambda_{\text {ex }}(\mathrm{nm})$ & $\lambda_{\text {em }}(\mathrm{nm})$ & $\Phi_{f}$ \\
\hline $\mathbf{1}$ & 375 & 539 & 0.035 \\
$\mathbf{7}$ & 494 & 646 & $<0.001$ \\
$\mathbf{8}$ & 426 & 569 & $<0.001$ \\
$\mathbf{9}$ & 387 & 547 & 0.133 \\
\hline
\end{tabular}

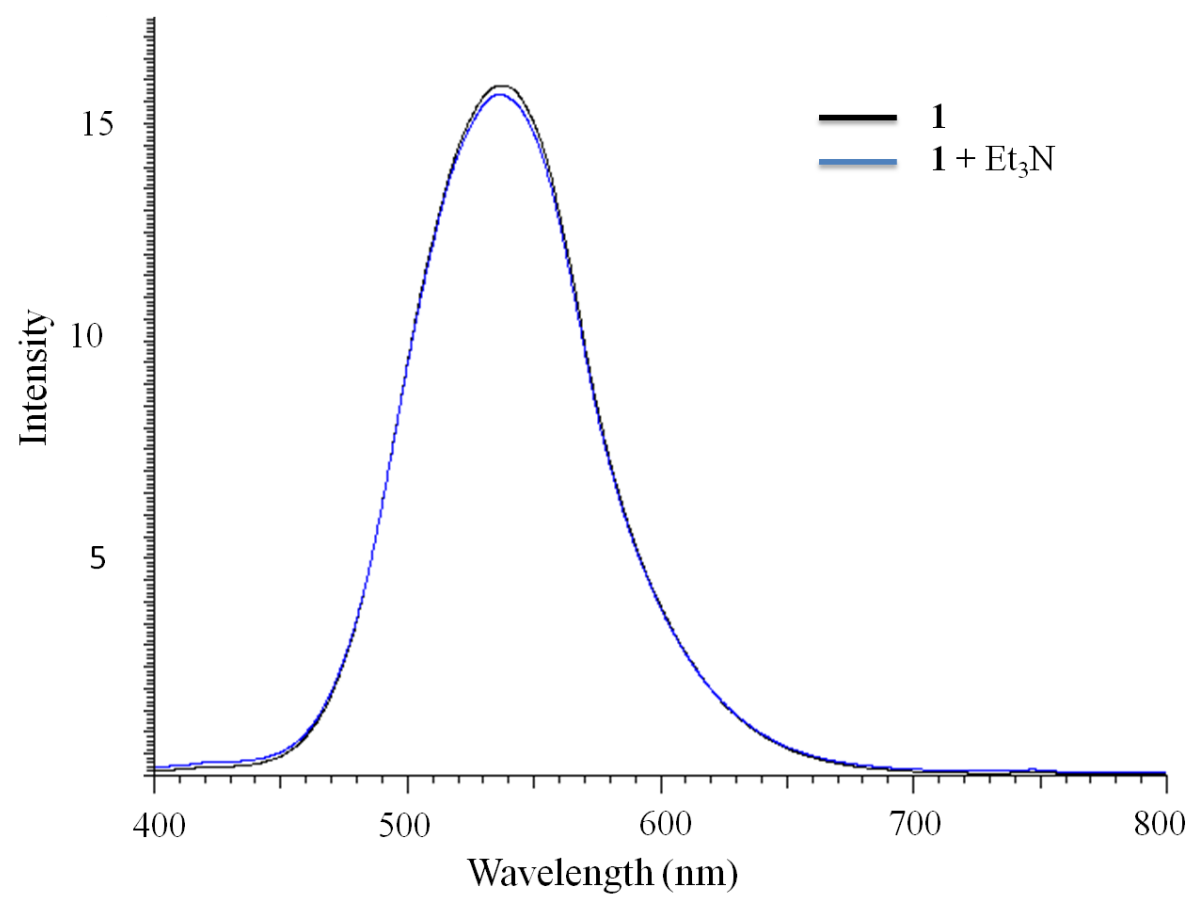

Figure 3. Fluorescence spectra of $\mathbf{1}$ in the absence and presence of excess triethylamine.

Figure 4 shows the reversible acidichromic behaviors of $\mathbf{1}$ during sequentially exposing it with an acid-base sequence. The results indicate that the reversible switching process between $\mathbf{1}$ and 7 can be repeated at least eight times without significant changes in the UV-vis spectra.

In addition to be interchangeable from one to the other via $\mathrm{pH}$ control, the two molecules $\mathbf{1}$ and 7 can also be further manipulated through exploitation of their redox potentials to convert them to their "pH-inert" forms. For instance, the acid-sensitive $\mathbf{1}$ can be oxidized by $N$ bromosuccinimide (NBS) to the acid-insensitive iminium bromide $\mathbf{8}$, whereas the base-sensitive 7 can be reduced by $\mathrm{NaBH}_{4}$ to the base-insensitive amine 9 (Scheme 2). Figure 5 shows the UVvis spectra of $\mathbf{8}$ and 9 prior to and after addition of $\mathrm{HBr}$ and $\mathrm{Et}_{3} \mathrm{~N}$. No major spectral variation between 350-500 $\mathrm{nm}$ was observed after the acid or base was added (the drastic absorbance increase of 9 between 230-350 nm under the basic conditions is due to the added triethylamine), implying that both $\mathbf{8}$ and $\mathbf{9}$ are now " $\mathrm{pH}$-inert". The fact that alternation of the $\mathrm{pH}$ after oxidation 
or reduction does not yield UV absorption bands correlating either $\mathbf{1}$ or $\mathbf{7}$, indicating that the reversible cyclization process indeed had been inhibited. Our studies have demonstrated that this lockable molecular switch system (Scheme 2) not only maintains the read-write and read-only behavior, but also provides color and emission variations to the on/off responses as easily detectable dual output properties. We believe the current switching system may find useful applications in future development of molecular devices that combine write-read-erase and write-read-lock mechanisms.

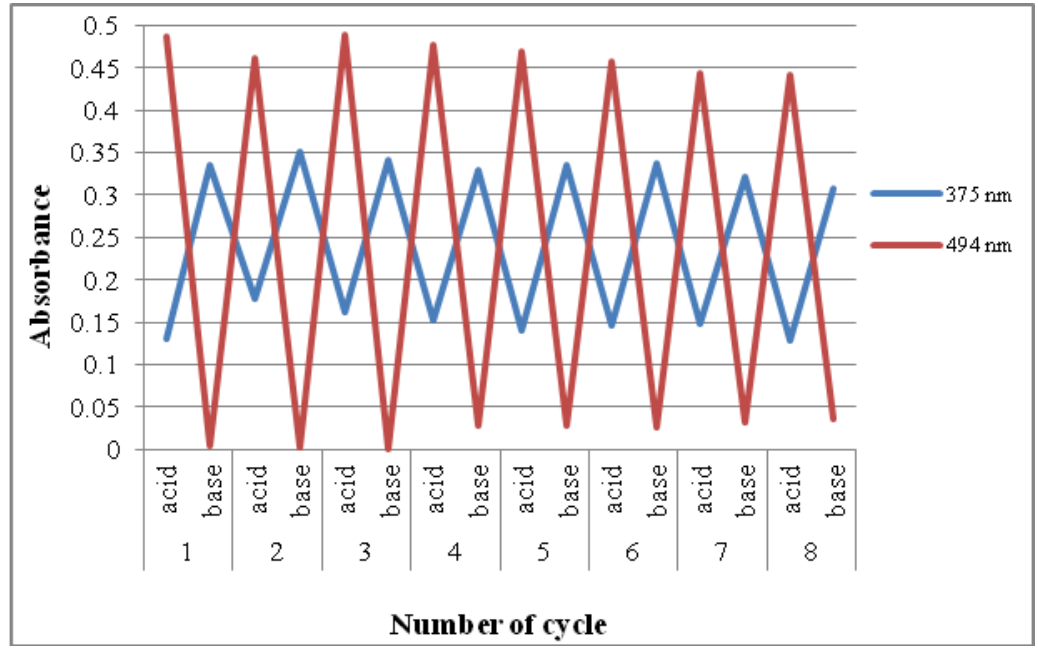

Figure 4. Reversible acidichromic behaviors of 1. Optical density variations at acidic (375 nm) and basic (494 nm) conditions during sequentially exposing 1 with an acid-base sequence in $\mathrm{CH}_{3} \mathrm{CN} / \mathrm{H}_{2} \mathrm{O}$ for eight cycles.

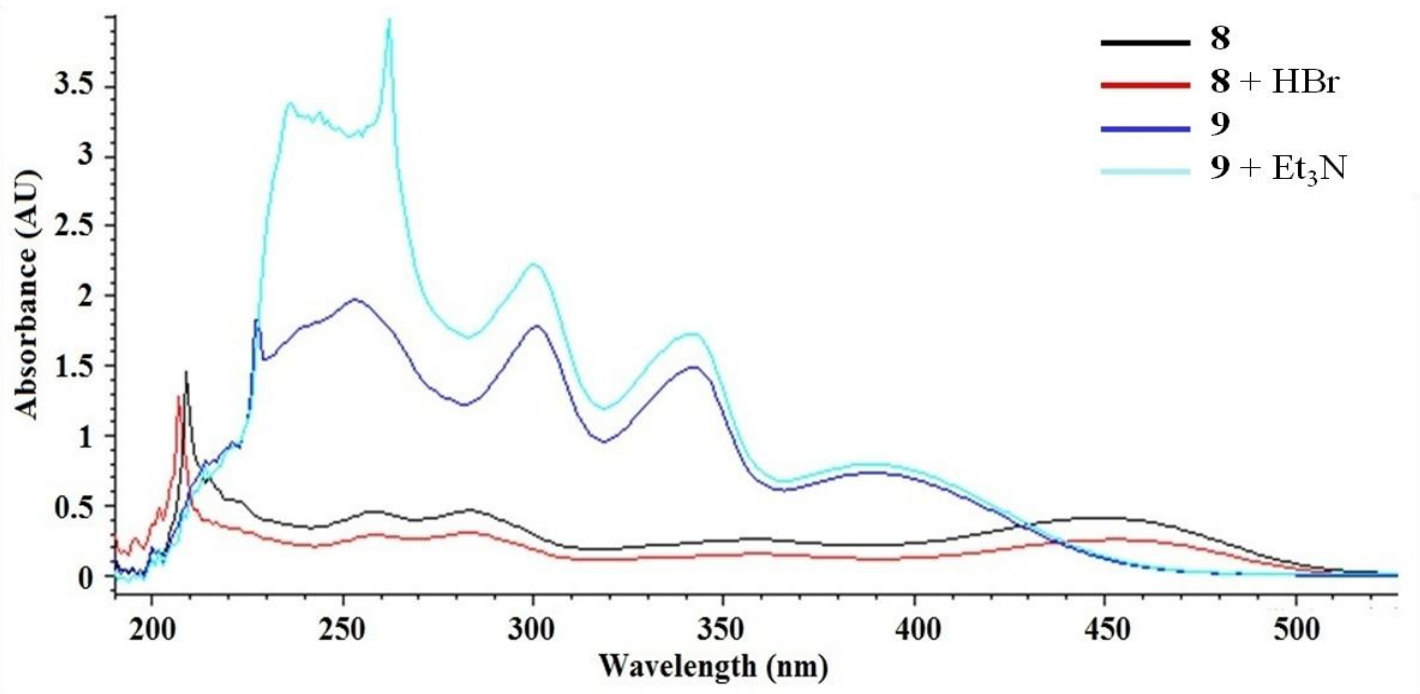

Figure 5. UV-vis spectra of 8 and $9\left(1.0 \times 10^{-5} \mathrm{M}^{\text {in }} \mathrm{CH}_{2} \mathrm{Cl}_{2} / \mathrm{H}_{2} \mathrm{O}\right)$ prior to and after addition of an acid $(\mathrm{HBr})$ or a base $\left(\mathrm{Et}_{3} \mathrm{~N}\right)$. 


\section{Conclusions}

In summary, the coumarin and phenanthridine-fused heterocycle 1 was efficiently synthesized using a base-mediated annulation of $N$-alkylquinolinium salt and coumarin as a key step. The prepared compound can function as an acidichromic colorant using an acid or a base as an external stimulus, along with easily detectable color and fluorescence variation as dual output properties. Moreover, the molecular switching between $\mathbf{1}$ and $\mathbf{7}$ is lockable via redox chemistry. They can be converted to their "pH-inert" forms by $\mathrm{NBS}$ oxidation and $\mathrm{NaBH}_{4}$ reduction. Further anchoring the amino group on the coumarin moiety of $\mathbf{1}$ onto a solid support to enhance its performance is currently underway.

\section{Experimental Section}

General. Melting points were determined on a Mel-Temp melting point apparatus in open capillaries and are uncorrected. MS were performed with a JEOL JMS-SX/SX 102A spectrometer. Absorption spectra were recorded using a HP8453 spectrophotometer. Fluorescence spectra were measured with a Hitachi F-4500 fluorescence spectrophotometer. 7Diethylamino-4-methylcoumarin $\left(\Phi_{\mathrm{f}}=1.00\right.$ in acetonitrile) was used as an external standard for the measurement of fluorescence quantum yields of 1 and 7-9. Fluorescence quantum yields were measured by comparing the integrated area under the fluorescence curve for $\mathbf{1}$ and 7-9 and 7-diethylamino-4-methylcoumarin at equal absorbance at the same excitation wavelength. The quantum yields were corrected for the refractive index of the solvent. ${ }^{1} \mathrm{H}$ and ${ }^{13} \mathrm{C}$ NMR spectra were recorded at 300 and $75 \mathrm{MHz}$ on a Varian VXR300 spectrometer or at 600 and $150 \mathrm{MHz}$ on a Varian VXR600 spectrometer. Chemical shifts were reported in parts per million on the $\delta$ scale relative to an internal standard (tetramethylsilane, or appropriate solvent peaks) with coupling constants given in hertz. ${ }^{1} \mathrm{H}$ NMR multiplicity data are denoted by s (singlet), $\mathrm{d}$ (doublet), $\mathrm{t}$ (triplet), q (quartet), and m (multiplet). Analytical thin-layer chromatography (TLC) was carried out on Merck silica gel 60G-254 plates $(25 \mathrm{~mm})$ and developed with the solvents mentioned. Flash chromatography was performed in columns of various diameters with Merck silica gel (230-400 mesh ASTM 9385 kieselgel 60H) by elution with the solvent systems. 4Methylquinoline, 1,2-dibromoethane, aniline and triethylamine were commercially available. The commercial chemicals were used as received. Solvents, unless otherwise specified, were reagent grade and distilled once prior to use. All new compounds exhibited satisfactory spectroscopic and analytical data. 7-Dimethylaminocoumarin was prepared according to the reported procedure. ${ }^{6}$

Synthetic procedure for 4-chloro-7-dimethylamino-2-oxo-2H-chromene-3-carbaldehyde (3). To a solution of DMF $(2 \mathrm{~mL})$ was added $\mathrm{POCl}_{3}(2 \mathrm{~mL})$ in one portion at $0{ }^{\circ} \mathrm{C}$. The resulting solution was heated at $50{ }^{\circ} \mathrm{C}$ for $0.5 \mathrm{~h}$. A solution of 7-dimethylaminocoumarin $(2,1.42 \mathrm{~g}, 6.71$ 
mmol, dissolved in $10 \mathrm{~mL}$ DMF) was then added to the mixture at that temperature. The mixture was further heated at $60{ }^{\circ} \mathrm{C}$ for $12 \mathrm{~h}$. After cooled to room temperature, the mixture was poured into ice-water and the precipitate was filtered. The cake was extracted with methylene chloride twice. The combined organic extracts were dried over $\mathrm{MgSO}_{4}$, filtered, and concentrated to obtain an orange solid; yield 92\%; $\mathrm{R}_{f}=0.45$ (40\% EtOAc/hexanes); mp 185-187 ${ }^{\circ} \mathrm{C} ;{ }^{1} \mathrm{H}$ NMR $\left(\mathrm{CDCl}_{3}, 300 \mathrm{MHz}\right) \delta 10.30(\mathrm{~s}, 1 \mathrm{H}), 7.86(\mathrm{~d}, J=9.3 \mathrm{~Hz}, 1 \mathrm{H}), 6.71(\mathrm{dd}, J=9.3,2.7 \mathrm{~Hz}, 1 \mathrm{H}), 6.44$ $(\mathrm{d}, J=2.7 \mathrm{~Hz}, 1 \mathrm{H}), 3.17(\mathrm{~s}, 6 \mathrm{H}) ;{ }^{13} \mathrm{C} \mathrm{NMR}\left(\mathrm{CDCl}_{3}, 75 \mathrm{MHz}\right) \delta 187.1,159.9,156.1,155.6$, 154.4, 129.1, 111.3, 110.9, 107.9, 97.0, 40.6; IR $v$ (KBr) 1718, 1681, 1615, 1555, 1504, 1384, 1146, $822 \mathrm{~cm}^{-1}$; HRMS (EI) calcd for $\mathrm{C}_{12} \mathrm{H}_{10} \mathrm{ClNO}_{3}\left[\mathrm{M}^{+}\right]$251.0349, found 251.0350.

2-Bromo-ethyl-4-methyl-quinolinium bromide (5). To a solution of 4-methylquinoline (4, 4.3 $\mathrm{g}$; $30 \mathrm{mmol})$ in 1,2-dibromoethane $(50 \mathrm{~mL})$ was heated at $90{ }^{\circ} \mathrm{C}$ for five days. Any precipitate formed during the reaction was recovered by filtration daily. After each filtration, the precipitate was rinsed with an additional $5 \mathrm{~mL}$ of 1,2-dibromoethane and the mother liquor stirred at $90{ }^{\circ} \mathrm{C}$ until the next filtration. The reaction was complete when no more precipitate formed. The precipitates were combined and washed thoroughly with acetone to give a beige solid; yield 88\%; mp 198-200 ${ }^{\circ} \mathrm{C}$ (lit. ${ }^{8 \mathrm{a}} 271-272{ }^{\circ} \mathrm{C}$ ); ${ }^{1} \mathrm{H}$ NMR (DMSO- $\left.d_{6}, 300 \mathrm{MHz}\right) \delta 9.45(\mathrm{~d}, J=6.0 \mathrm{~Hz}$, $1 \mathrm{H}), 8.64(\mathrm{~d}, J=5.7 \mathrm{~Hz}, 1 \mathrm{H}), 8.57(\mathrm{dd}, J=5.7,1.2 \mathrm{~Hz}, 1 \mathrm{H}), 8.26(\mathrm{ddd}, J=8.4,7.2,1.5 \mathrm{~Hz}, 1 \mathrm{H})$, $8.14(\mathrm{~d}, J=6.0 \mathrm{~Hz}, 1 \mathrm{H}), 8.06(\mathrm{td}, J=7.5,0.9 \mathrm{~Hz}, 1 \mathrm{H}), 5.49(\mathrm{t}, J=6.0 \mathrm{~Hz}, 2 \mathrm{H}), 4.13(\mathrm{t}, J=6.0$ $\mathrm{Hz}, 2 \mathrm{H}), 3.03$ (s, 3H).

\section{2-(Dimethylamino)-1-phenyl-2,3-dihydro-1H-chromeno[3,4-j]imidazo[1,2-}

f]phenanthridin-15(16bH)-one (1). To a solution of $\mathbf{3}$ (205 $\mathrm{mg}, 0.81 \mathrm{mmol})$ in ethanol (12 mL) was added 2-bromoethyl-4-methylquinolinium bromide (5, $268 \mathrm{mg}, 0.81 \mathrm{mmol})$ and triethylamine $(169 \mu \mathrm{L}, 1.21 \mathrm{mmol})$ at room temperature. The resulting solution was refluxed for $4 \mathrm{~h}$. After cooled to room temperature, the precipitate was filtered to give a red solid $\mathbf{6}$. To this red compound 6 (200 mg, $0.38 \mathrm{mmol})$ in $\mathrm{CHCl}_{3}(10 \mathrm{~mL})$ was added aniline $(34 \mu \mathrm{L}, 0.38 \mathrm{mmol})$ and triethylamine $(160 \mu \mathrm{L}, 1.14 \mathrm{mmol})$ at room temperature. The resulting solution was stirred at that temperature for $4 \mathrm{~h}$. After the reaction was complete, the mixture was transferred to a separating funnel and washed with water $(15 \mathrm{~mL})$ and brine $(5 \mathrm{~mL})$. The organic phase was then dried over $\mathrm{MgSO}_{4}$ and concentrated. The crude product was purified by column chromatography to give a light yellow solid; yield $36 \%$ (from 3 and 5); $\mathrm{R}_{f}=0.22$ (50\% EtOAc/hexanes); mp 238$240{ }^{\circ} \mathrm{C} ;{ }^{1} \mathrm{H} \mathrm{NMR}\left(\mathrm{CDCl}_{3}, 300 \mathrm{MHz}\right) \delta 8.24(\mathrm{~s}, 1 \mathrm{H}), 8.05(\mathrm{~s}, 1 \mathrm{H}), 8.03(\mathrm{~d}, J=6.3 \mathrm{~Hz}, 1 \mathrm{H}), 7.97$ $(\mathrm{d}, J=9.3 \mathrm{~Hz}, 1 \mathrm{H}), 7.41(\mathrm{td}, J=7.5,1.2 \mathrm{~Hz}, 1 \mathrm{H}), 7.31-7.25(\mathrm{~m}, 2 \mathrm{H}), 7.08(\mathrm{td}, J=7.2,1.2 \mathrm{~Hz}$, $1 \mathrm{H}), 6.86(\mathrm{td}, J=6.3,0.9 \mathrm{~Hz}, 2 \mathrm{H}), 6.75-6.73(\mathrm{~m}, 3 \mathrm{H}), 6.59(\mathrm{~d}, J=2.4 \mathrm{~Hz}, 1 \mathrm{H}), 5.37(\mathrm{~s}, 1 \mathrm{H})$, 4.12-4.04 (m, 1H), 3.97-3.92 (m, 1H), 3.70-3.65 (m, 1H), 3.40-3.36 (m, 1H), $3.60(\mathrm{~s}, 6 \mathrm{H}) ;{ }^{13} \mathrm{C}$ $\mathrm{NMR}\left(\mathrm{CDCl}_{3}, 150 \mathrm{MHz}\right) \delta 161.7,153.1,151.9,148.3,144.4,138.2,135.5,132.9,130.9,129.3$, 126.4, 124.6, 123.5, 123.0, 120.0, 118.6, 115.0, 113.8, 113.4, 112.6, 109.1, 106.8, 99.3, 75.1, 50.8, 44.8, 40.2; IR $v$ (KBr) 2924, 2853, 1721, 1617, 1362, 1244, 1133, $750 \mathrm{~cm}^{-1}$; HRMS (EI) $\mathrm{m} / \mathrm{z}$ calcd for $\mathrm{C}_{30} \mathrm{H}_{25} \mathrm{~N}_{3} \mathrm{O}_{2}\left[\mathrm{M}^{+}\right]$459.1947, found 459.1936 .

3-(Dimethylamino)-6-oxo-9-(2-(phenylamino)ethyl)-6H-chromeno[3,4-j]phenanthridin-9ium bromide (7). To a solution of $5(100 \mathrm{mg}, 0.22 \mathrm{mmol})$ in methylene chloride $(5 \mathrm{~mL})$ was 
added water $(5 \mathrm{~mL})$. Phases were separated and then extracted into excess $47 \% \mathrm{HBr}(1 \mathrm{~mL})$. The acidic extract was concentrated under vacuum and the residue was triturated with acetone to afford a red solid as the product; yield 82\%; mp $230{ }^{\circ} \mathrm{C}$ (dec.); ${ }^{1} \mathrm{H}$ NMR (DMSO- $\left.d_{6}, 600 \mathrm{MHz}\right) \delta$ $10.01(\mathrm{~s}, 1 \mathrm{H}), 9.43$ (d, $J=8.4 \mathrm{~Hz}, 1 \mathrm{H}), 9.39$ (s, 1H), $9.17(\mathrm{~s}, 1 \mathrm{H}), 8.60$ (d, $J=9.6 \mathrm{~Hz}, 1 \mathrm{H}), 8.57$ $(\mathrm{d}, J=7.8 \mathrm{~Hz}, 1 \mathrm{H}), 8.14(\mathrm{t}, J=7.2 \mathrm{~Hz}, 1 \mathrm{H}), 8.09(\mathrm{t}, J=7.2 \mathrm{~Hz}, 1 \mathrm{H}), 7.05(\mathrm{t}, J=7.8 \mathrm{~Hz}, 2 \mathrm{H})$, $6.83(\mathrm{dd}, J=9.6,1.8 \mathrm{~Hz}, 1 \mathrm{H}), 6.59-6.54(\mathrm{~m}, 4 \mathrm{H}), 5.86(\mathrm{~s}, 1 \mathrm{H}), 5.10-5.09(\mathrm{~m}, 2 \mathrm{H}), 3.83-3.70$ $(\mathrm{m}, 2 \mathrm{H}), 3.09(\mathrm{~s}, 6 \mathrm{H}) ;{ }^{13} \mathrm{C}$ NMR (DMSO-d, $\left.150 \mathrm{MHz}\right) \delta 159.6,155.4,153.9,153.8,147.4$, 141.9 , 137.2, 137.1, 133.9, 132.9, 130.0, 129.1, 127.1, 126.4, 125.2, 120.8, 120.3, 119.7, 116.7, 114.0, 112.3, 109.8, 104.9, 98.2, 56.7, 41.6, 39.6; IR v (KBr) 3391, 3016, 2566, 1744, 1598, 1377, 1119, 761, $616 \mathrm{~cm}^{-1}$; HRMS (EI) m/z calcd for $\mathrm{C}_{30} \mathrm{H}_{26} \mathrm{BrN}_{3} \mathrm{O}_{2}\left[\mathrm{M}^{+}\right]$539.1208, found 539.1205 .

\section{2-(Dimethylamino)-15-oxo-1-phenyl-1,2,3,15-tetrahydrochromeno[3,4-j]imidazo[1,2-}

f]phenanthridin-4-ium bromide (8). To a solution of $\mathbf{1}$ (70 $\mathrm{mg}, 0.15 \mathrm{mmol})$ in ethyl acetate (12 $\mathrm{mL}$ ) was added $N$-bromosuccinimide $(30 \mathrm{mg}, 0.17 \mathrm{mmol}$ ) at room temperature for $3 \mathrm{~h}$ in the dark. The precipitate was filtered and washed with ethyl acetate to give a brown solid; yield $88 \%$; mp $330{ }^{\circ} \mathrm{C}$ (dec.); ${ }^{1} \mathrm{H} \mathrm{NMR}\left(\mathrm{CD}_{3} \mathrm{OD}, 300 \mathrm{MHz}\right) \delta 8.91(\mathrm{~s}, 1 \mathrm{H}), 8.78(\mathrm{~d}, J=8.1 \mathrm{~Hz}, 1 \mathrm{H})$, $8.19(\mathrm{~d}, J=9.0 \mathrm{~Hz}, 1 \mathrm{H}), 8.06(\mathrm{~s}, 1 \mathrm{H}), 7.89(\mathrm{t}, J=8.1 \mathrm{~Hz}, 1 \mathrm{H}), 7.76-7.62(\mathrm{~m}, 7 \mathrm{H}), 6.73(\mathrm{dd}, J=$ 9.0, 2.7 Hz, 1H), $6.36(\mathrm{~d}, J=2.7 \mathrm{~Hz}, 1 \mathrm{H}), 4.98-4.80(\mathrm{~m}, 2 \mathrm{H}), 4.70-4.60(\mathrm{~m}, 2 \mathrm{H}), 3.05(\mathrm{~s}, 6 \mathrm{H})$; ${ }^{13} \mathrm{C}$ NMR $\left(\mathrm{CD}_{3} \mathrm{OD}, 150 \mathrm{MHz}\right) \delta 160.9,155.0,154.9,153.7,141.2,140.2,139.9,134.8,133.8$, 132.8, 132.6, 132.0, 127.9, 127.1, 126.8, 126.4, 121.3, 119.2, 117.0, 115.8, 113.1, 110.9, 105.4, 99.0, 55.7, 48.0, 40.2; IR $v(\mathrm{KBr}) 3403,1733,1610,1570,1545,1388,1269,1131,775 \mathrm{~cm}^{-1}$; HRMS (FAB) $\mathrm{m} / \mathrm{z}$ calcd for $\mathrm{C}_{30} \mathrm{H}_{24} \mathrm{BrN}_{3} \mathrm{O}_{2}\left[\mathrm{M}+\mathrm{H}^{+}\right]$538.1130, found 538.1131.

\section{3-(Dimethylamino)-9-(2-(phenylamino)ethyl)-8,9-dihydro-6H-chromeno[3,4-}

j]phenanthridin-6-one (9). To a solution of $7(100 \mathrm{mg}, 0.19 \mathrm{mmol})$ in methanol $(25 \mathrm{~mL})$ was added sodium borohydride $(21 \mathrm{mg}, 0.56 \mathrm{mmol})$ in one portion at room temperature. The red solution turned yellow instantly. After completion of the reaction within $5 \mathrm{~min}$, and the crude product was purified by column chromatography to give an orange solid; yield $83 \% ; \mathrm{R}_{f}=0.23$ (20\% EtOAc/hexanes); mp 185-187 ${ }^{\circ} \mathrm{C} ;{ }^{1} \mathrm{H} \mathrm{NMR}\left(\mathrm{CDCl}_{3}, 300 \mathrm{MHz}\right) \delta 8.18(\mathrm{~s}, 1 \mathrm{H}), 8.03(\mathrm{~s}$, $1 \mathrm{H}), 7.95(\mathrm{~d}, J=9.0 \mathrm{~Hz}, 1 \mathrm{H}), 7.91(\mathrm{dd}, J=7.8,1.2 \mathrm{~Hz}, 1 \mathrm{H}), 7.31(\mathrm{td}, J=8.4,1.5 \mathrm{~Hz}, 1 \mathrm{H}), 7.19$ $(\mathrm{td}, J=7.5,1.2 \mathrm{~Hz}, 2 \mathrm{H}), 6.93(\mathrm{t}, J=6.9 \mathrm{~Hz}, 1 \mathrm{H}), 6.87(\mathrm{~d}, J=8.4 \mathrm{~Hz}, 1 \mathrm{H}), 6.73(\mathrm{t}, J=7.5 \mathrm{~Hz}$, $1 \mathrm{H}), 6.72(\mathrm{dd}, J=9.0,2.7 \mathrm{~Hz}, 1 \mathrm{H}), 6.63(\mathrm{dd}, J=8.7,1.2 \mathrm{~Hz}, 2 \mathrm{H}), 6.60(\mathrm{~d}, J=2.4 \mathrm{~Hz}, 1 \mathrm{H}), 4.38$ $(\mathrm{s}, 2 \mathrm{H}), 3.86(\mathrm{~s}, 1 \mathrm{H}), 3.47(\mathrm{t}, J=5.7 \mathrm{~Hz}, 2 \mathrm{H}), 3.06(\mathrm{t}, J=5.7 \mathrm{~Hz}, 2 \mathrm{H}), 3.07(\mathrm{~s}, 6 \mathrm{H}) ;{ }^{13} \mathrm{C} \mathrm{NMR}$ $\left(\mathrm{CDCl}_{3}, 75 \mathrm{MHz}\right) \delta 161.8,152.8,151.7,147.7,146.9,138.2,135.3,131.1,130.8,129.3,127.0$, 125.0, 123.2, 121.9, 118.5, 117.8, 117.4, 113.5, 113.0, 112.9, 109.1, 106.8, 99.2, 52.4, 49.7, 40.4, 40.1; IR $v(\mathrm{KBr}) 3371,1706,1620,1604,1496,1282,1131 \mathrm{~cm}^{-1}$; HRMS (EI) $\mathrm{m} / \mathrm{z}$ calcd for $\mathrm{C}_{30} \mathrm{H}_{27} \mathrm{~N}_{3} \mathrm{O}_{2}\left[\mathrm{M}^{+}\right]$461.2103, found 461.2115.

Reversible acidichromic behaviors of 1 . The initial sample was prepared as a $9.8 \times 10^{-5} \mathrm{M}$ solution of compound $1\left(1.35 \mathrm{mg}, 2.94 \times 10^{-3} \mathrm{mmol}\right)$ in $15 \mathrm{~mL}$ of $\mathrm{CH}_{3} \mathrm{CN}$ and $15 \mathrm{~mL}$ of $\mathrm{H}_{2} \mathrm{O}$. With a drop of $47 \% \operatorname{HBr}_{(\mathrm{aq})}$ to reduce the $\mathrm{pH}$ of the mixture to $\sim 3$ and the UV-vis spectra of the 
solution (at $494 \mathrm{~nm}$ ) was measured. The resulting solution was then basified to $\sim \mathrm{pH} 9$ by dropwise addition of triethylamine and its UV-vis spectra (at $375 \mathrm{~nm}$ ) was measured. This cycle was repeated eight times.

UV-vis spectra of 8 and 9 prior to and after addition of an acid or a base. For compound 8 , the initial sample was prepared as a solution of compound $8\left(1.35 \mathrm{mg}, 2.51 \times 10^{-3} \mathrm{mmol}\right)$ in 10 $\mathrm{mL}$ of $\mathrm{CH}_{2} \mathrm{Cl}_{2}$ and $10 \mathrm{~mL}$ of $\mathrm{H}_{2} \mathrm{O}$. The $\mathrm{UV}$-vis spectra were obtained for the organic layer. The biphasic solution was then acidified by drop-wise addition of $47 \% \mathrm{HBr}_{(\mathrm{aq})}$ to reduce the $\mathrm{pH}$ to $\sim 3$, and the UV-vis spectra were obtained again for the organic layer. For compound 9 , the initial sample was prepared as a solution of compound $9\left(0.63 \mathrm{mg}, 1.36 \times 10^{-3} \mathrm{mmol}\right)$ in $10 \mathrm{~mL}$ of $\mathrm{CH}_{2} \mathrm{Cl}_{2}$ and $10 \mathrm{~mL}$ of $\mathrm{H}_{2} \mathrm{O}$. The $\mathrm{UV}$-vis spectra were obtained for the organic layer. Triethylamine was then added drop-wise to the biphasic solution to basify the aqueous layer to the $\mathrm{pH} \sim 9$, and the UV-vis spectra were obtained again for the organic layer.

\section{Acknowledgements}

We thank the National Science Council of the Republic of China, Taiwan, for financially supporting this research under Contract No. NSC 98-2113-M-029-003-MY2.

\section{References}

1. (a) Credi, A.; Balzani, V.; Langford, S. J.; Stoddart, J. F. J. Am. Chem. Soc. 1997, 119, 2679. (b) Szacilowski, K.; Macyk, W.; Stochel, G. J. Am. Chem. Soc. 2006, 128, 4550.

2. (a) Shiraishi, Y.; Tokitoh, Y.; Nishimura, G.; Hirai, T. Org. Lett. 2005, 7, 2611. (b) Tashiro, R.; Sugiyama, H. J. Am. Chem. Soc. 2005, 127, 2094. (c) Kawai, S. H.; Gilat, S. L.; Ponsinet, R.; Lehn, J. M. Chem.-Eur. J. 1995, 1, 285. (d) D’Souza, F.; Chitta, R.; Gadde, S.; Zandler, M. E.; McCarty, A. L.; Sandanayaka, A. S. D.; Araki, Y.; Ito, O. J. Phys. Chem. A 2006, 110, 4338.

3. (a) Richmond, C. J.; Parenty, A. D. C.; Song, Y.-F.; Cooke, G.; Cronin, L. J. Am. Chem. Soc. 2008, 130, 13059-13065. (b) Richmond, C. J.; Eadie, R. M.; Parenty, A. D. C.; Cronin, L. J. Org. Chem. 2009, 74, 8196.

4. (a) Kawai, S. H.; Gilat, S. L.; Lehn, J. M. J. Chem. Soc., Chem. Commun. 1994, 8, 1011. (b) Tsivgoulis, G. M.; Lehn, J. M. Chem.-Eur. J. 1996, 2, 1399. (c) Pina, F.; Melo, M. J.; Maestri, M.; Ballardini, R.; Balzani, V. J. Am. Chem. Soc. 1997, 119, 5556. (d) Pina, F.; Lima, J. C.; Parola, A. J.; Afonso, C. A. M. Angew. Chem., Int. Ed. 2004, 43, 1525.

5. (a) Goulle, V.; Harriman, A.; Lehn, J. M. J. Chem. Soc., Chem. Commun. 1993, 1034. (b) Bethell, D.; Dougherty, G.; Cupertino, D. C. J. Chem. Soc., Chem. Commun. 1995, 675. (c) Canevet, C.; Libman, J.; Shanzer, A. Angew. Chem., Int. Ed. 1996, 35, 2657. (d) Collin, J. 
P.; Dietrich-Buchecker, C.; Gavina, P.; Jimenez-Molero, M. C.; Sauvage, J. P. Acc. Chem. Res. 2001, 34, 477. (e) Pease, A. R.; Jeppesen, J. O.; Stoddart, J. F.; Luo, Y.; Collier, C. P.; Heath, J. R. Acc. Chem. Res. 2001, 34, 433.

6. Chen, Y. S.; Kuo, P. Y.; Shie, T. L.; Yang, D. Y. Tetrahedron 2006, 62, 9410.

7. Chen, J. J.; Li, K. T.; Yang, D. Y. Org. Lett. 2011, 13, 1658.

8. (a) Parenty, A. D. C.; Song, Y.-F.; Richmond, C. J.; Cronin, L. Org. Lett. 2007, 9, 2253. (b) Parenty, A. D. C.; Cronin, L. Synthesis 2008, 1, 155. 